The Trial Trip of the "Florida"

$\mathrm{N}$ a rough sea and a brisk wind the "Florida" averaged 21.974 knots on five top-speed runs over the Rockland course on March 25th. That record gives her the blue ribbon. That record gives her the places her beside the British dreadnought "Vanguard" in point of speed. On one of her five runs the "Florida" made 22.54 knots, which is just a shade better than the "Vanguard's" 22.50 , and appreciably better than the "Utah's" 21.637 knots, the best hitherto attained by an American ship.

As we have pointed out previously, the "Florida" is an exceptional vessel. In the first place, she was built by the Government itself at the Brooklyn Navy Yard, under conditions distinctly less favorable than those that obtain in private yards, thereby demonstrating that our naval constructors are capable of building the largest and most modern warships. In the second place, she may be regarded as the last word in warship design; for both the "Florida" and her sister ship the "Utah" are rated as the best protected warships afloat.

The "Florida" is a 21,825-ton battleship with a length of 521 feet 6 inches, a beam of 88 feet $21 / 2$ inches, and a mean draft of 28 feet 6 inches (with two-thirds full supplies, store and fuel and full supply ammunition). She is driven by Parsons turbines working on four shafts, which turbines are by contract required to develop 28,000 horsepower. This propelling machinery was to give her an average speed of 20.75 knots, which she exceeded as we have seen. The "Florida" will store, when completed, some 400 tons of oil fuel in addition to 2,500 tons of coal. It will be remembered that the "North Dakota" and "Delaware" are likewise provided with oil-tanks in addition to coal bunkers.

The "Florida" is armed like the "North Dakota," with ten 12-inch guns, but instead of fourteen 5-inch torpedo-repelling guns she carries sixteen. The 12 -inch guns are mounted in five turrets on the center line of the ship. In point of armor protection, the "Florida" leaves nothing to be desired. Her belt armor varies from 12 inches to 8 inches in thickness; her turret armor is 12 inches, and her battery armor $61 / 2$ inches. Her smokestacks are protected by $91 / 2$ inches. Against torpedo attack the "Florida" is safeguarded by an elaborate subdivision of the hull and an unusually powerful pumping plant for removing such water as may enter.

\section{Perils of the Deck-load} By James G. McCurdy

THE deck-load has always been an important factor in the lumber carrying trade out of Puget Sound ports. Vessels of every rig that have been identified with the traffic since its inception have added ma-

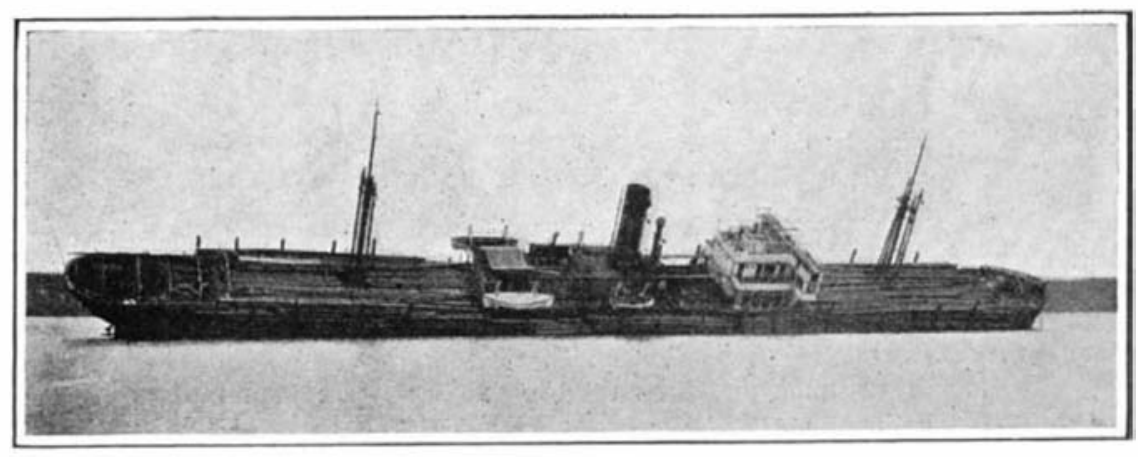

This vessel got into trouble because her water-ballast tanks were not fully flled.

German steamer "Wotan" as she returned to port.

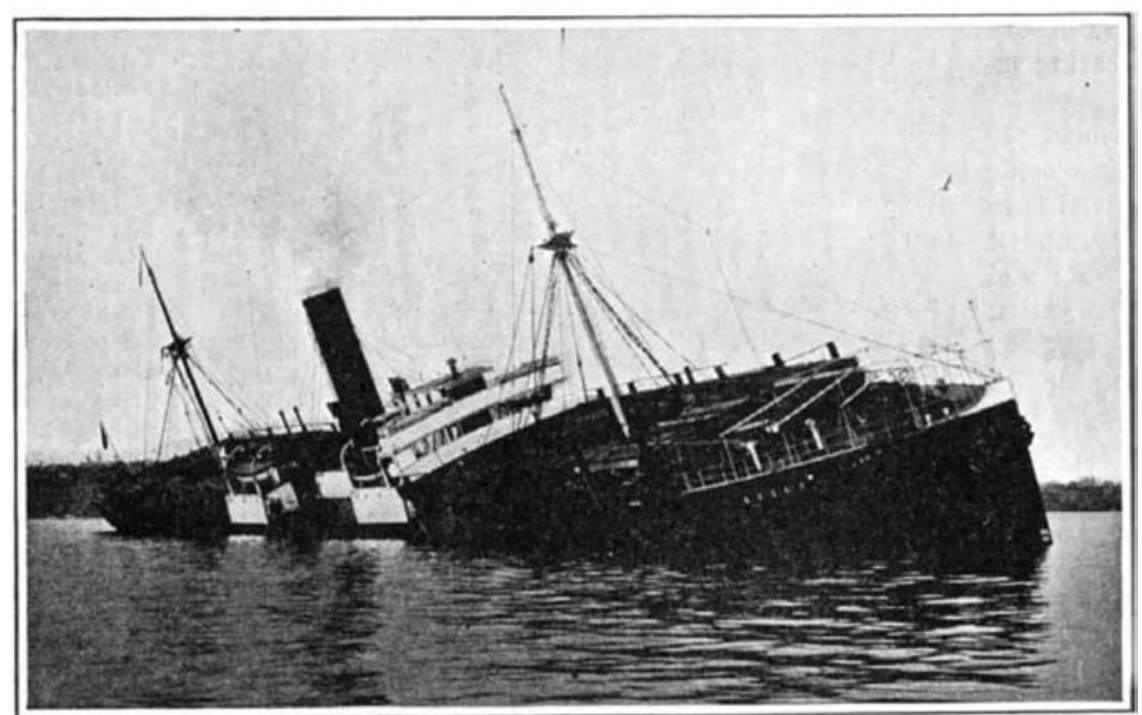

During a storm the deckload of $1,400,000$ fect of humber shifted.

Norwegian steamer "Cuzco," listed 23 degrees.

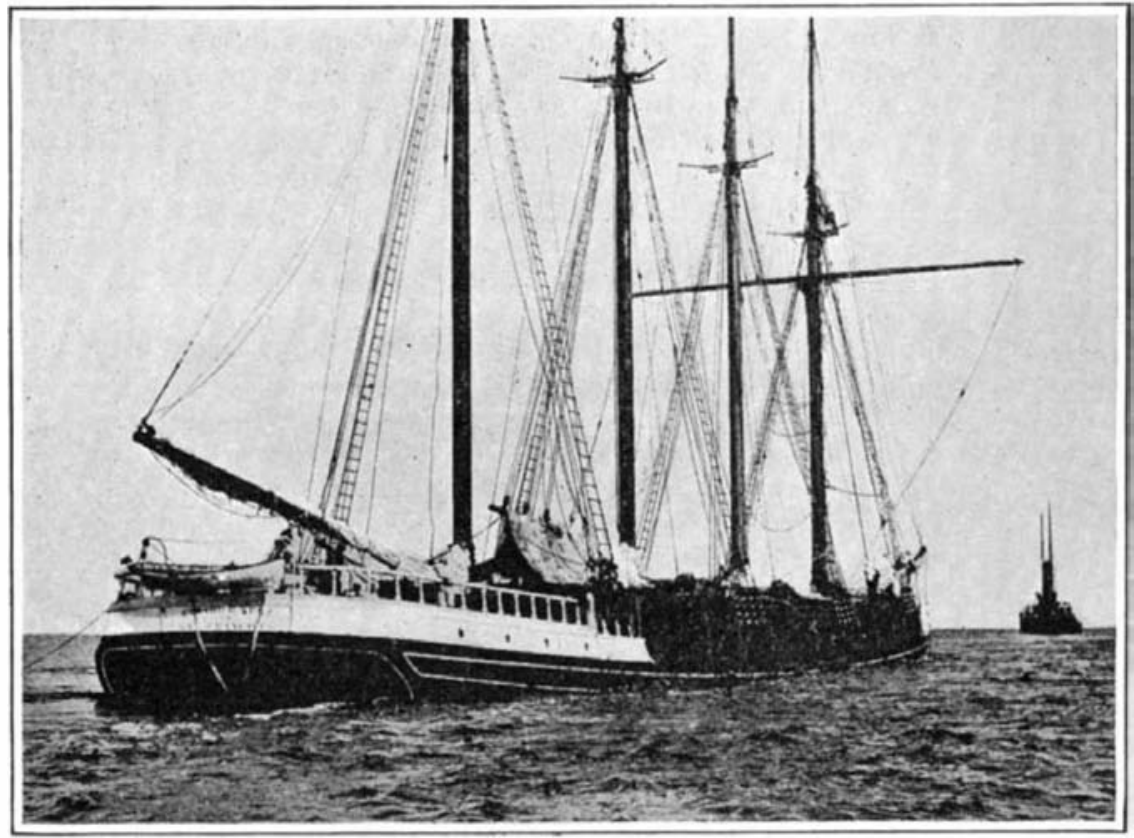

A frequent mishap to sohooners engaged in the lumber tracle.

This four-masted schooner is waterlogged. PERILS OF 'I'HE DECK-LOAD terially to their carrying capacity by being able to take a large percentage of their cargoes stowed on deck; and indeed but few dividends could have been earned had this not been possible.

Square-rigged craft, the pioneers of the trade, confined their deck-loads to spars and other large timbers. In vessels of the schooner build and rig deck-loads reached their maximum, fully three-fourths as much lumber being carried on deck as beneath it. The large steamships that have entered the trade of late years are following the example of the schooners, and leave port with deck-loads towering high above the rail.

A moderate, well-stowed and properly lashed deck-load does not constitute an element of risk. In fact, schooners are said to run steadier and handle better with a deckload than without it. But when a vessel puts to sea with a deck-load that is excessive, badly stowed or improperly secured, she goes forth handicapped from the start and in poor condition to cope with the heavy weather.

Our navigation laws make it incumbent upon the owner or agent of any sea-going craft to indicate the draught at which he shall deem his vessel safe to be loaded for the trade in which she is engaged, the draught to be specified in the certificate of inspection; and they make it unlawful to load deeper than said line.

But this law is really a dead letter, for at least three reasons. First, it is left for the owner to set his own load line; and it is safe to assume that rersonal interest will enter largely into the question. Seoond, the load line is not plainly indicated as in the English merchant marine, where the Plimsol mark is painted conspicuously upon the vessel's hull, thus maling over-loading instantly apparent. Third, there is no government inspection to ascertain whether a vessel is overloaded or not.

It is natural that those who charter vessels should endeavor to load them to their fullest capacity, and the only check to overloading is the inspector who looks over the cargo in the interests of the marine underwriters. That the inspector is not infallible is shown by the frequency of accidents at sea, many of which can be traced directly to over-loading. Take for example the case of the big British freighter "Argus."

This vessel, after taking on a large quantity of lumber at one of the Puget Sound saw mills, was proceeding to Bellingham to complete cargo. Her deck-load was one of the largest ever put aboard of a vessel reaching a height of 30 feet aft and 26 feet forward, above the deck.

While en route, without warning she went over on her beam ends to such a degree that the smokestack was almost on a level with the water. About 300,000 feet of lumber broke loose from the deck-load, en(Concluded on page s16.)

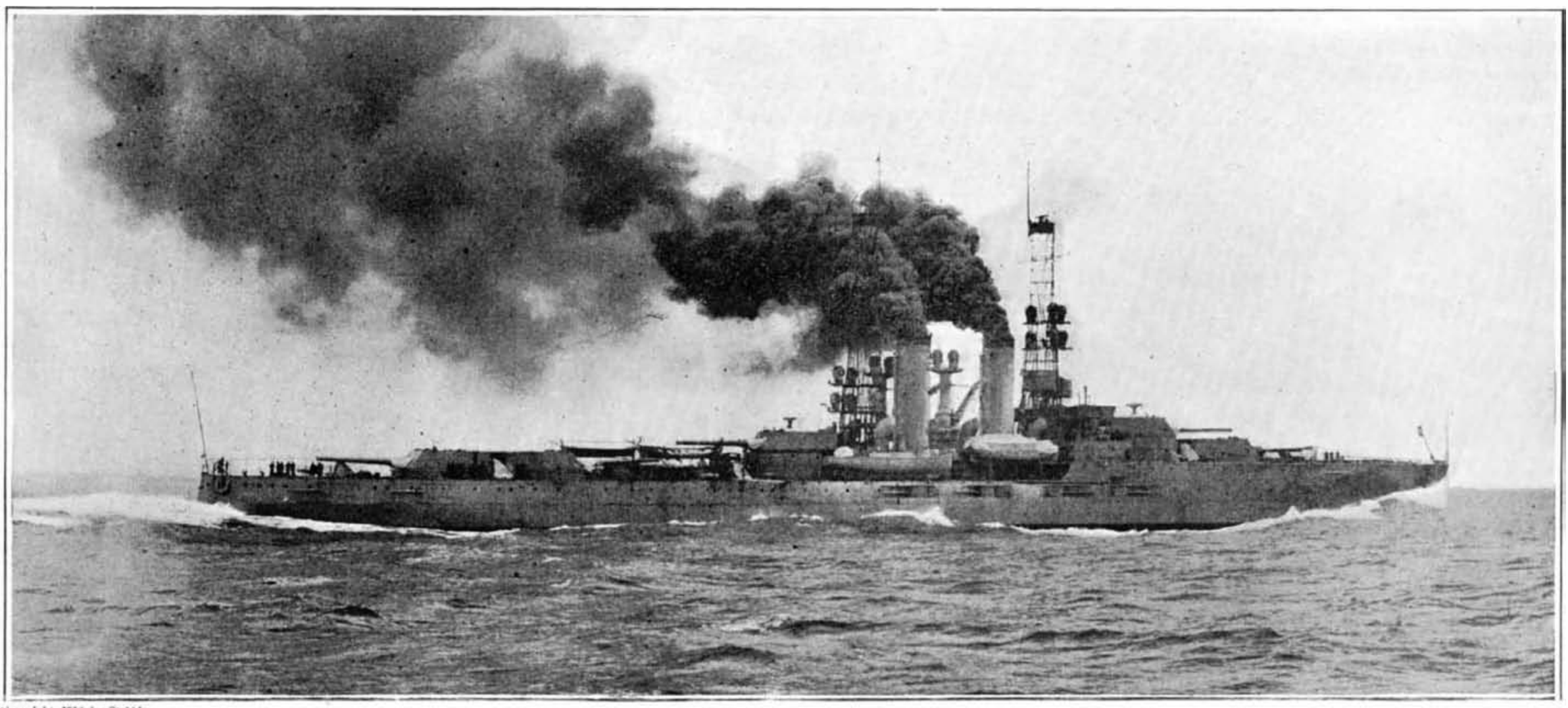

THE BATTLESHP “FLORIDA” PLOWING ThROUGH THE SEA AT A SPEED OF 22.54 KNOTS ON HER TRIAL TRIP OFF RUCKLAND, MAINE. 


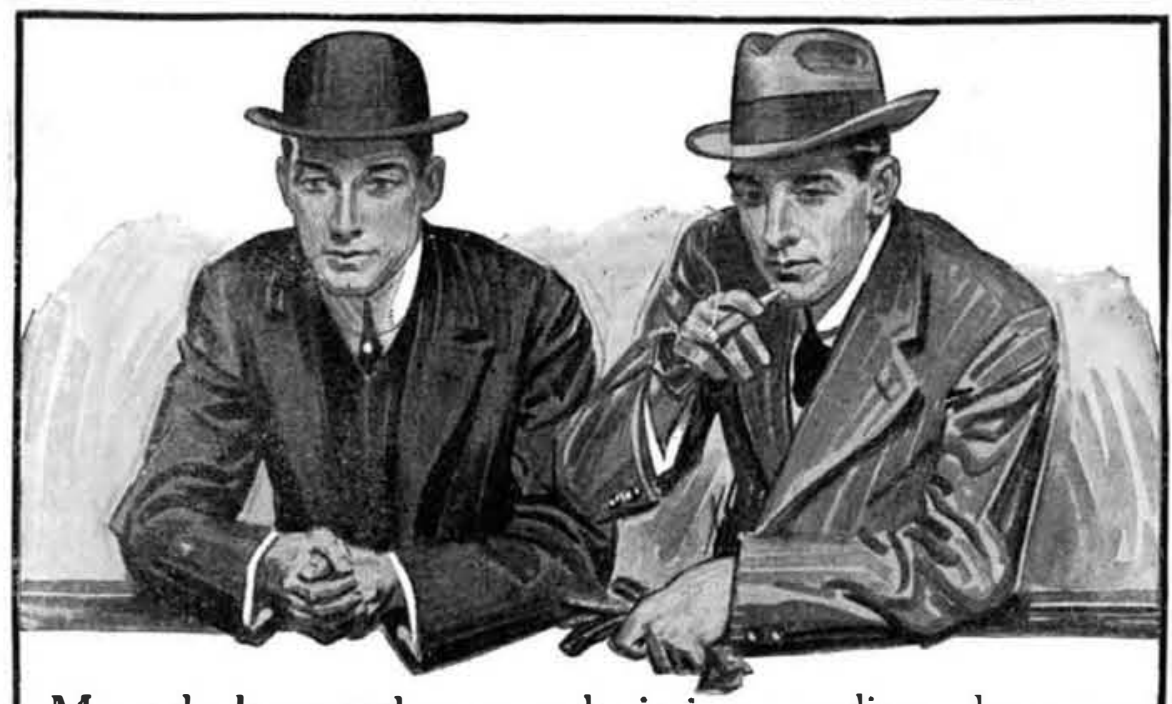

Men who know style-men who insist on quality and wearare the ones who are today making the nation-wide demand for

\section{"0or "Correct Styles for Men"}

You're absolutely sure of the quality when you put on a von - whether stiff or soft. It is guaranteed to you by the dealer and we stand behind him. The new spring styles include the newest and best rough, scratch and bright finish effects.

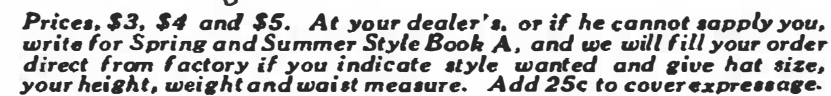

We are Makers of the 7 Celebrated \$3 Hat

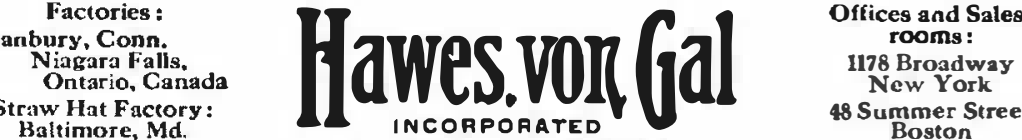
INCORPOAATED
Panama Factory: New York

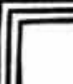 \\ That Corn Will Go for Good

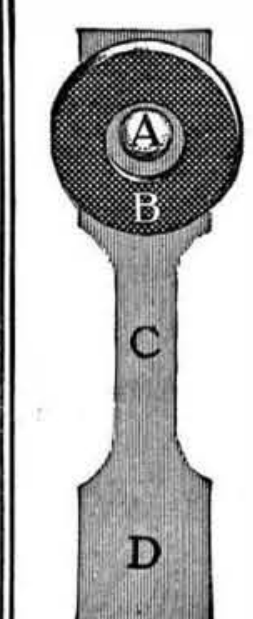 \\ It will be ended forever in 48 hours, if you use a Blue- jay plaster. \\ The pain ends in- stantly when yo apply it. Then the B \& B wax gently In two days it comes out, root and all. \\ No soreness, no discomfort. Nothing Thown does what Blue-jay does. will never let corns disturb you when you find this out. \\ Nor will you ever pare them. Par- ing takes off just the top of the corn. And a slip of the blade means infec- Th-sometimes a dangerous one. The right way - the easy way - is to mous Blue-jay plaster. Proveit today. \\ A In the picture is the soft $B \& B$ wax. It loose B protects the corn, stopping the pain at once. \\ Blue-jay Corn Plasters \\ Sold by Druggists-15c and 25c per package Sample Mailed Free. Also Blue-jay Bunion Plaster \\ Bauer \& Black, Chicago and New York, Makers of B \& B Handy Package Absorbent Cotton, etc.}

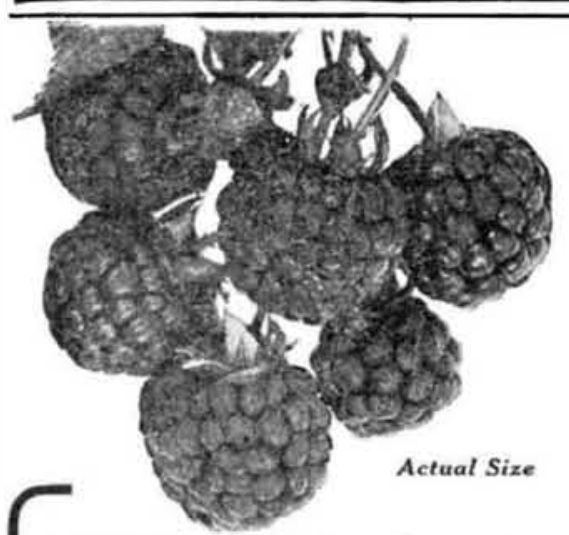

St. Regis Everbearing The Raspberry for the Million and the
Millionaire. "There's Millions InIt."

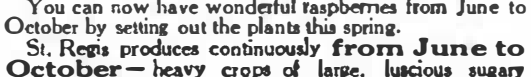

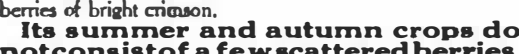

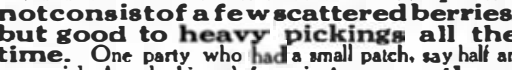

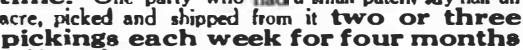

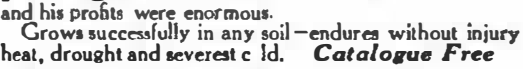

Northern States

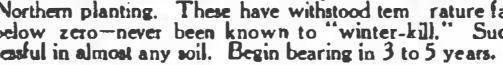

till the latest member had developed two giant bony horns, several feet long, domMost of the best preserved skulls and fossil remains of these animals have bee giscovered in the single geographic
gion, now the Big Bad Lands of the $\mathrm{Da}-$ kotas, and in a continúous series of de posits, known as the "White Rive These titanotherium beds have left wonderful panorama of the life-history of the animals and show that they went
through their entire final evolution and through their entire final evolution and extinction in a short period of two hunthough the dominant and most formidable animals of their day, suddenly became extinct at the close of the Lowe
Oligocene Age. Their extinction is at tributed principally to their defective grinding teeth not being adapted to the changed conditions of vegetation and velopment of grassy uplands favored the evolution and existence of herbivorous plains-living, open country, types, ligh teeth and elongated feet. Herds of small fleet horses which existed in enormous fleet horses which existed in enormous
numbers, together with other grazing animals in the regions of South Dakota and Nebraska, it is thought, may have cut off large part of the food supply of the titanotheres, thereby aiding toward their final extinction. Prof. Osborn is preparing, with the assistance of Mr. W. K. monograph on the titanotheres from the rich and remarkable material obtained by various museum expeditions for the and greatly extond all knowledge as to
these little known animal inhabitants

\section{Perils ot the Deck-load} (Concluded from page 308.)

abling the vessel to partly right herself. Some lumber, however, got foul of the propeller and brought the steamship to a sudden stop. Only the prompt let-
ting go of the anchors prevented the craft going ashore.

Arriving at Bellingham, an effort was made to replace the lost portion of the deck load, when the vessel again went over on her side, her smokestack and masts resting against the face of the dock. The crew scrambled ashore along hints, stakestack. After two such emphatic what and the vessel put to sea and armishap.

Stowe of ballast tanks, makes a deck load a me the that would under other circumstances be perfectly safe

Some months ago the German steamship "Wotan" took on a heavy deck load consisting of large timbers and creosoted piling, and she was proceeding out of beam ends with a suddenness that threw her crew into a panic. She was brought her crew into a panic. She was brought but did not right herself until a large percentage of the deck load was removed.
The underwriters' agent, who investigated the case, claimed that the accident was due to the fact that the water ballast tanks were but partly filled. Apparently this was a reasonable contention; for after the tanks had received proper atten-
tion the piling was replaced and the vestion the piling was replaced and the vessel put to sea on an even keel.
A few months later the Norwegian steamship "Cuzco" had even a more thrilling experience. She had left Puget sisting in part of $2,800,000$ feet of lumber, about half of which was in the form 16 feet above the bulwarks.

The vessel had hardly cleared the coast when she ran into a storm of unusual broadside, and careening under the force of the blow, her deck load shifted, rying the steamship over to an angle of 35 degrees. Here she lay, threatening to turn turtle any instant. The steering craft was practically helpless. Although the deck load projected fully six feet beyond the bulwarks, only one 000 feet of lumber.

\section{TEMPERATURE \\ problems are best solved by the aid of $\rightleftharpoons$ "Tycos"}

\section{Thermometers}

\section{Pyrometers, and other Instruments for the} Indicating, Recording and Regulating of Temperature and Pressure. No requirements too severe for "Tycos" Products.

Write us about your proposition
Faylor Instrument Companios

111 Ames St., ROCHESTER, N. Y.

"Where "Tycos" Thermometers Come From"

Rubber Specialties Made or Parker, Stearns \& Co. Incorporate

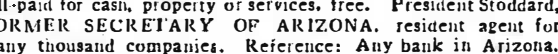
TODDARD INCORPORATING COMPANY, Box 8000 WELL DRILLING MACHINES

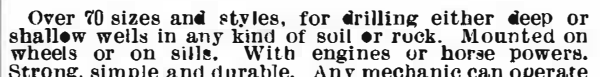
WILLIAMS BROS., Ithaca, N. Y.
W. A DURYEA

is the simplest Auto made.
Several styles. Catalogue free.
c. S. DURYEA Co., Saginaw, Mich. FAMTOI AUBRICATIS SED

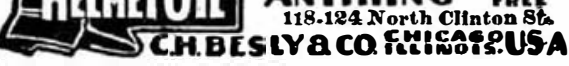
SELENIUM AND ITS REMARKABLE PROPERTIES are fully described in Scientific American Supplement 1430. The paper is illustrated yumerous engravings. Price 10 cents. For sale
y Monn Co., Inc., and all newsdealers.

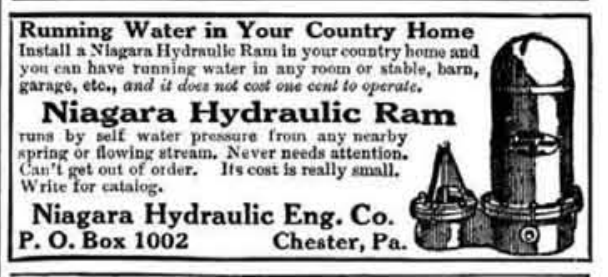

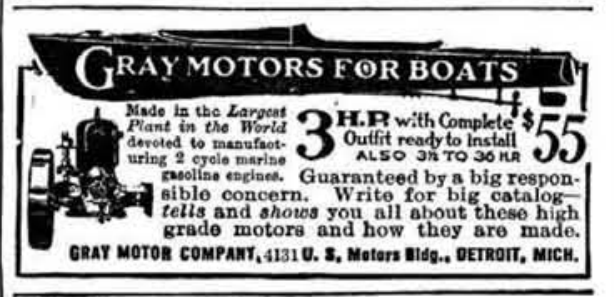

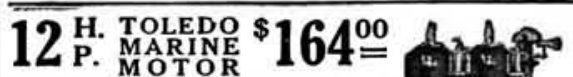
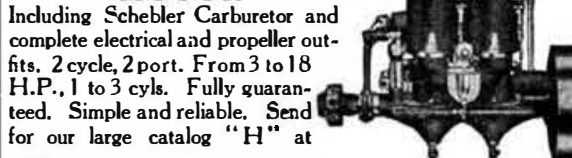

THE UNIVERSAL MACHINE C 0 . South St., Bowling Green, 0 .

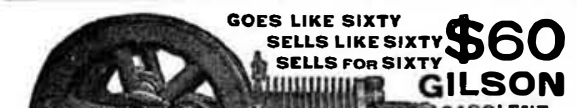

1 12 S

Separators, Churns, Wash Ma-
chines, ect. $Z B D E$ TRIAI

Trees for Planting in

in Nore are Pecan Trees which will thrive

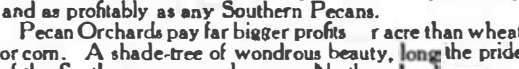

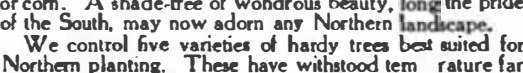

\$150 KERMATH $\$ 150$

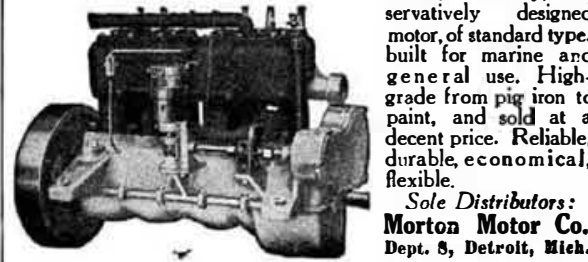



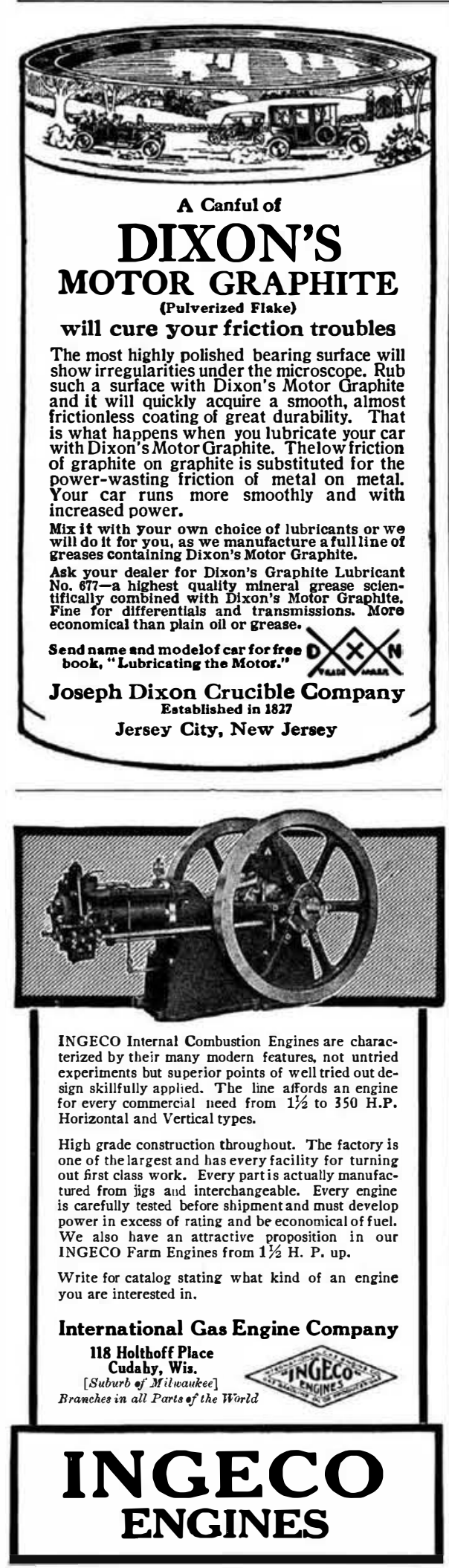

OILDAG
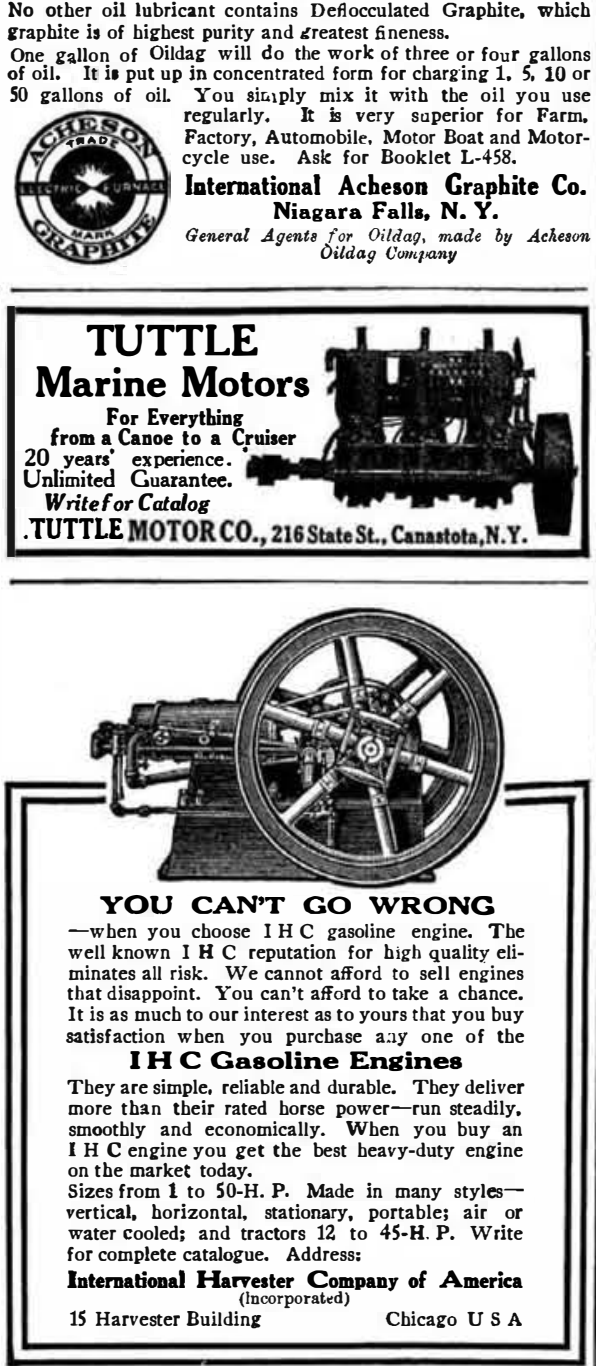

ble, the lashings would have been let go and the deck load sacrificed to ease the ship. But this action was not possible, in the trough of the sea, taking in water rapidly through hatches and rivet holes. By good seamanship the vessel was turned about and brought slowly back to port, retaining a list of 23 degrees. The mainmast shrouds and stays had been carried away, the mast bent and the bulwarks torn out.

These accidents, and many more that ight be enumerated, have had a tendwriters to the perils of aners and underload, and the desirability of an improved method of securing deck cargoes. It is masters who have to take the risks, that deck loads should bear a certain specified ratio to the between deck cargo, taking into consideration the construction and rig of the various vessels, and that there should be government inspection to prevent overloading.

In regard to deck lashings, it has been contended that some uniform system of fastenings should be brought into use, whereby in moments of grave peril the deck load could be released promptly and without danger. Heretofore there seems
to have been a tendency to secure the to have been a tendency to secure the
deck load so thoroughly that it could not deck load so thoroughly that it could not break away under any circumstance. tricate maze and are so securely fastened with turn-buckles that it is impossible, no matter how great the need, to let go the cek load and relieve the vessel without effort

A fastening is already in vogue consistng of a hook so secured by a link that a but for some reason it has not come into popular use. The use of such a fastening, or an improved form, will probably result from the present agitation. Perhaps a fastening will be perfected that will act automatically when subjected to xtraordinary strain, such as arises when a vesse

\section{Improving on Darwin`}

organisms, and he has restated the known facts of heredity in terms of "genotypes." As a result of his experi-
ments he concluded that selection can never establish genotypical differences, nd that therefore, "natural selection" could never have given rise to new species. His conclusions are in perfect DeVries, as well as with the results of the many experimenters on "Mendelism." Johannsen's ideas help to explain the observations of breeders that certain
characters can neither be made to blend by crossing, nor can they be increased nor reduced in any way.

The expression "unit characters" has een used by many writers for the idea or animal is made up; for example, the color, hairiness or baldness, dimensious, early or late ripening, etc., have been considered units, and breeders have expected these qualities to appear as
wholes in the plants or animals with which they were working. Johannsen does not speak of unit characters; expects most characters to be the exr more factors. In this he is in accord with such experimenters as Castle, Punnett, Correns and others. The factors
are the units that are concerned in eredity. This view readily explains such facts, for example, as "reversions to type" ssume the ancestral trait in question to be the realized reaction of two or more inherited factors, we can see how it has failed to show itself in two or mor strains for many generations: each
strain had one or several of the factors, ut not all. On crossing two distinct "we factors necessary for prother in one individual and the result a reversion to the ancestral type. This kind of reversion has been produced at
will over and over again by many experiwill over and over again by many exper
menters, with pigeons, rabbits, mice, poultry,

In rejecting the idea of purpose in cre-

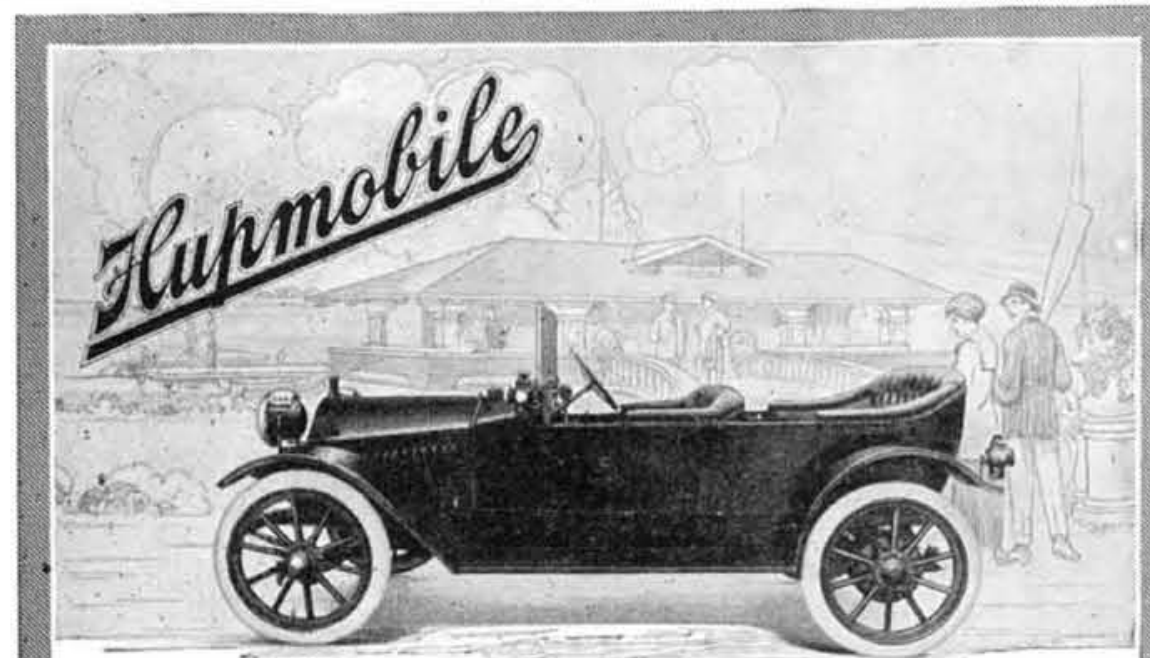

Huomobile Long-Stroke "32" Touring Car, $\$ 900$

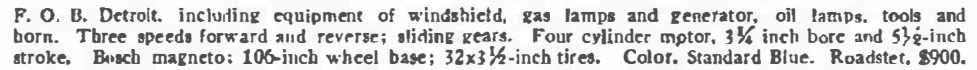

Not the Price; Not the Specifications; Butthe Name added to both

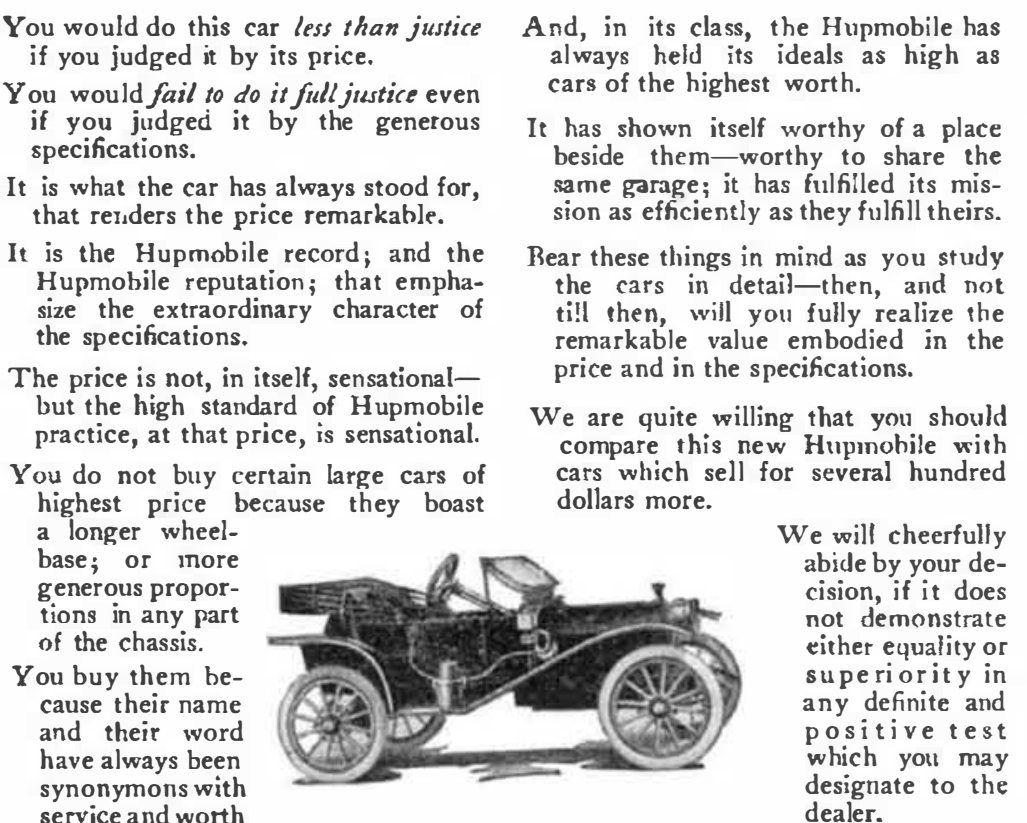

vice and worth

Standard 20 H.P. Runabout, 9750

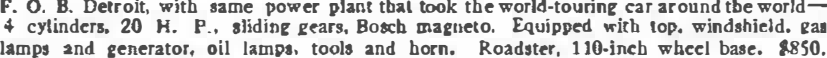

Hupp Motor Car Co., 1233 Jefferson Ave., Detroit, Mich.

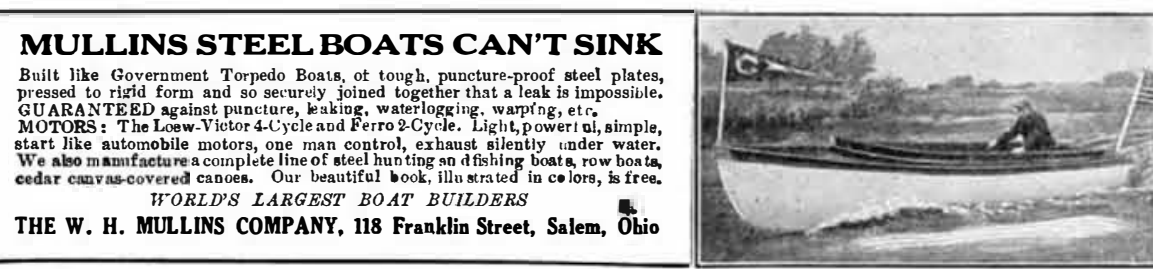

An Orchard Investment Where the Orchard is Most Profitable On the Sunny Southern slopes of the Blue Ridge Mountains in Northeast Georgia. Opportunity is stretching out her hand to you. Natural advantages possessed by no other Orchard District insure the highest quality in fruit at the lowest production cost, and it is 2500 miles nearer the markets than the Western apple. Location strongly endorsed by the highest authorities. An interest in our the
orchard is yours on easy terms. It is your one best chance. Write now for full particulars.

APPALACHIAN APPLE ORCHARDS, 1020 CANDLER BUILDING, ATLANTA, GA.

Business Law for the Busy Man Mail the Coupon for FREE Examination

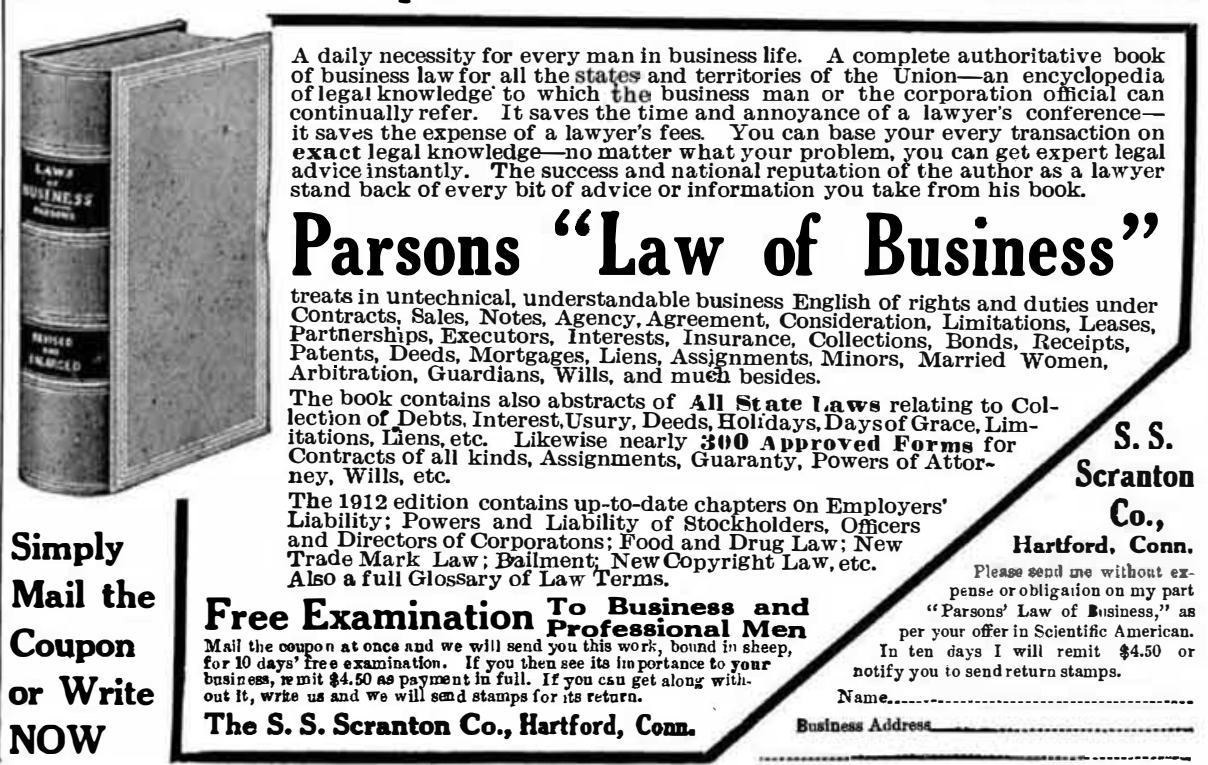

